\title{
ANALISIS PENGUNGKAPAN CORPORATE SOCIAL RESPONSIBILITY BERDASARKAN GLOBAL REPORTING INITIATIVE G4
}

\author{
Crista Fianica Wulolo \\ Isna Putri Rahmawati \\ Universitas Sebelas Maret \\ e-mail: cfianica94@gmail.com
}

\begin{abstract}
This study aims to analyze the quantity and quality disclosure of CSR (Corporate Social Responsibility) using reporting guidance Global Reporting Initiative (GRI), which consists of ten aspects, namely strategy and organization, organizational profile, material aspects and boundary identified, Stakeholders, reporting profiles, governance, aspects and integrity, economic, environmental, and social. The sample in this research is mining companies listed on BEl in 2014 and 2015 as many as 32 companies. The research method used is descriptive analysis, with analysis technique in the form of content analysis. The results show that the average quantity and quality of CSR disclosure in mining companies in 2014 and 2015 is still low.
\end{abstract}

Keywords: Quantity of CSR disclosure, CSR disclosure quality, GRI G4

\begin{abstract}
ABSTRAK
Penelitian ini bertujuan untuk menganalisis kuantitas dan kualitas pengungkapan CSR (Corporate Social Responsibility) dengan menggunakan pedoman pelaporan keberlanjutan GRI (Global Reporting Initiative) G4, yang terdiri dari sepuluh aspek, yaitu strategi dan organisasi, profil organisasi, aspek materiak dan boundary teridentifikasi, hubungan dengan pemangku kepentingan, profil laporan, tata kelola, aspek dan integritas, ekonomi, lingkungan, dan sosial. Sampel dalam penelitian ini adalah perusahaan sektor pertambangan yang terdaftar di BEl tahun 2014 dan 2015 sebanyak 32 perusahaan. Metode penelitian yang digunakan adalah analisis deskriptif, dengan teknik analisis berupa content analysis. Hasil penelitian menunjukkan bahwa rata-rata kuantitas dan kualitas pengungkapan CSR pada perusahaan sektor pertambangan tahun 2014 dan 2015 masih tergolong rendah.
\end{abstract}

Kata kunci: kuantitas pengungkapan CSR, kualitas pengungkapan CSR, GRI G4

Corporate Social Responsibility saat ini menjadi sebuah perhatian yang besar bagi dunia. Hal ini dikarenakan CSR mempengaruhi peran perusahaan terhadap masalah-masalah umum aktivitas perusahaan, seperti lingkungan dan etika sosial. Berbagai masalah umum aktivitas perusahaan seperti kerusakan lingkungan, perlakuan yang tidak layak terhadap tenaga kerja, cacat produksi yang membahayakan konsumen, telah menjadi rahasia umum bagi masyarakat dunia. Oleh karena itu, banyak negara di dunia membuat serta menerapkan aturan-aturan yang ketat, baik dalam hal 
regulasi maupun standar (McWilliams dan Siegel, 2001). Hal ini merupakan wujud perhatian mereka terhadap masalah lingkungan-sosial dunia, yang seharusnya menjadi kesadaran pribadi masyarakat dunia.

Elkington (1997) menyatakan bahwa istilah CSR tidak lepas dari konsep Tri Bottom Line (TBL) yang terdiri dari 3P, yaitu people, planet, dan profit. Ketiga pilar utama ini merupakan ukuran wajib yang digunakan untuk mengukur tingkat kesuksesan suatu perusahaan dengan tiga kualifikasi, yakni ekonomi, lingkungan, dan sosial. Noviana (2010) menjelaskan bahwa perusahaan tidak lagi sekedar memikirkan profit, melainkan perusahaan wajib mewujudnyatakan implikasi dari konsep TBL.

Salah satu dari sekian standar pelaporan yang dijadikan kerangka kerja untuk akuntansi sosial, audit, dan pelaporan adalah Global Reporting Initiative's (GRI) Sustainability Reporting Guidelines. GRI adalah salah satu organisasi di dunia yang menghasilkan standar pelaporan paling banyak yang digunakan untuk sustainability reporting atau pelaporan berkelanjutan. Pembaharuan dan revisi pedoman GRI ini terjadi hingga generasi keempat, yaitu G4 yang diterbitkan pada bulan Mei 2013. Pedoman ini dibuat dengan tujuan agar organisasi pelaporan dapat mengungkapkan dampak yang paling penting, baik positif maupun negatif, pada lingkungan, masyarakat, dan ekonomi. Tujuan yang lain adalah organisasi pelapor mampu menghasilkan informasi yang dapat dipercaya, relevan, dan dapat digunakan untuk menilai setiap peluang maupun risiko, dan mengungkapkan lebih banyak informasi guna pengambilan keputusan yang tepat.

Pengungkapan (disclosure) merupakan penyajian sejumlah informasi yang dikumpulkan oleh perusahaan (Hendriksen, 1991). Pengungkapan CSR merupakan media komunikasi antara perusahaan dengan stakeholders perusahaan. Tujuan dari pengungkapan informasi CSR adalah untuk membangun, mempertahankan, dan melegitimasi apa yang telah perusahaan kontribusikan dari sudut pandang ekonomis dan politis. Tujuan berikutnya adalah pemberian informasi tentang seberapa jauh perusahaan telah melakukan kontribusi yang positif atau negatif terhadap stakeholders, khusunya dalam hal sosial dan lingkungan (Guthrie dan Parker, dalam Sayekti et al, 2007).

\section{Pedoman Pelaporan Berkelanjutan GRI G4}

Pedoman pelaporan berkelanjutan G4 menyajikan prinsip-prinsip pelaporan dan pengungkapan standar, serta panduan penerapan. Dalam Pedoman G4, ada dua jenis pengungkapan standar, yaitu pengungkapan standar umum dan pengungkapan standar khusus. Pengungkapan standar umum terdiri dari 7 aspek, yaitu: 1) Strategi dan Analisis yang memberikan gambaran strategis secara umum mengenai keberlanjutan organisasi, untuk memberikan konteks pada bagian laporan selanjutnya yang lebih detail dibandingkan bagian-bagian dalam pedoman; 2) Profil Organisasi merupakan gambaran keseluruhan tentang karakteristik organisasi, untuk memberikan konteks bagi rincian-rincian dalam laporan dibandingkan dengan bagian-bagian yang ada dalam pedoman; 3) Aspek Material dan Boundary Teridentifikasi memberikan gambaran keseluruhan tentang proses yang telah diikuti oleh organisasi untuk menetukan konten laporan, aspek material dan boundary teridentifikasi, serta pernyataan ulang; 4) Hubungan dengan Pemangku Kepentingan adalah gambaran keseluruhan tentang hubungan dengan pemangku kepentingan organisasi selama periode pelaporan. Pengungkapan standar ini tidak hanya terbatas pada keterlibatan yang dilakukan untuk tujuan penyusutan laporan; 5) Profil Laporan menyajikan gambaran keseluruhan tentang informasi dasar mengenai laporan, indeks konten GRI, dan pendekatan untuk memperoleh assurance eksternal; 6) Tata Kelola memberikan gambaran 
keseluruhan tentang struktur tata kelola dan komposisinya; peran badan tata kelola tertinggi dalam menetapkan tujuan, nilai, dan strategi organisasi; kompetensi dan evaluasi kerja badan tata kelola tertinggi; peran badan tata kelola tertinggi dalam manajemen risiko; peran badan tata kelola tertinggi dalam pelaporan keberlanjutan; peran badan tata kelola tertinggi dalam mengevaluasi kinerja ekonomi, lingkungan, dan sosial; remunerasi dan insentif; 7) Etika dan Integritas merupakan gambaran keseluruhan tentang nilai, prinsip, standar, dan norma di organisasi; mekanisme internal dan eksternal untuk memperoleh masukan mengenai perilaku etis dan taat hukum; serta mekanisme internal dan ekternal untuk melaporkan permasalahan tentang perilaku yang tidak etis atau melanggar hukum dan masalah integritas.

Sedangkan pengungkapan standar khusus terdiri dari pengungkapan pendekatan manajemen dan indikator-indikator kategori dan aspek. Pengungkapan pendekatan manajemen bertujuan untuk memberikan kesempatan bagi organisasi untuk menerangkan bagaiman pengelolaan dampak ekonomi, lingkungan, dan sosial yang berkaitan dengan aspek material.

\section{Perbedaan Antara GRI G3.1 dengan GRI G4}

GRI mengeluarkan standar baru, bernama G4, pada tanggal 22 Mei 2013, di Amsterdam. G4 memuat lebih banyak perubahan standar yang signifikan, jika dibandingkan dengan standar sebelumnya, yaitu G3.1. Fokus perubahan pertama adalah isu-isu yang material. Materialitas yang digambarkan oleh G4 adalah bentuk persilangan antara signifikansi dampak ekonomi, sosial, dan lingkungan organisasi pelapor dengan perngaruh terhadap penilaian dan keputusan kepentingan. Sedangkan fokus kedua dalam pedoman G4 adalah menghilangkan level aplikasi pada pedoman GRI sebelumnya. Fokus kedua ini diwujudkan sebagai bentuk dari tanggapan para pakar yang mengamati bahwa penggunaan level aplikasi $A, B$, dan $C$ menjadikan kesalahpahaman bagi banyak organisasi. Fokus ketiga dari G4 adalah ekspansi batas-batas pelaporan. Ini berarti setiap organisasi pelapor harus mengulas kinerja bekerlanjutan, dimulai dari rantai pasokan hingga rantai pasarnya. Fokus keempat adalah penekanan pada unsur tata kelola dan etika. Hal ini menjelaskan bahwa G4 akan menunjukkan bagaimana fungsi organisasi pengawas, seperti dewan komisaris perusahaan dan peran sumber daya manusia lainnya (Tempo, 2013).

Penelitian ini dimotivasi oleh penelitian Bonilla-Priego et al (2014) dan Anggarani (2016). Bonilla-Priego (2014) menggunakan pengungkapan standar GRI G3.1 sebagai dasar pengukurannya pada perusahaan pelayaran besar di dunia di tahun 2011. Sedangkan Anggarani (2016) sudah menggunakan GRI G4 dalam pedoman analisisnya pada perusahaan sektor indutri semen, pertambangan, dan perbankan di tahun 2013-2014. Pada penelitian ini menggunakan sektor pertambangan yang terdaftar pada BEI pada periode 2014-2015. Hal ini mengingat bahwa GRI.G4 baru diterbitkan pada Mei 2013 sehingga baru dapat dilihat kepatuhannya pada tahun berikutnya.

Hasil dari penelitian diharapkan mampu memberikan gambaran luasnya pengungkapan CSR pada perusahaan pertambangan yang terdaftar di Bursa Efek Indonesia periode 2014 dan 2015. Hal ini dikarenakan sector pertambangan merupakan salah satu sektor yang dalam usahanya banyak mengeksplorasi alam.

\section{METODE PENELITIAN Populasi dan Sampel}

Perusahaan yang menjadi sampel dalam penelitian ini adalah perusahaan dengan kriteria yaitu perusahaan pertambangan yang telah terdaftar di BEI tahun 2014 dan 2015 serta Perusahaan pertambangan yang terdaftar di BEl yang menerbitkan laporan tahunan (annual report) dan laporan 
keberlanjutan (sustainability report) tahun 2014 dan 2015. Sampel yang sesuai dengan kriteria adalah 32 perusahaan dengan total observasi sebanyak 64. Peneliti memilih perusahaan pertambangan karena banyak perusahaan pertambangan yang terus mengejar peningkatan efisiensi kegiatan perusahaan dan merangsang kreativitas serta inovasi baru. Hal ini tidak hanya memberikan pengaruh bagi lingkungan, contohnya polusi, tetapi juga pengaruh sosial, seperti inovasi dan daya saing (WBCSD, 2000). Selain itu aktivitas perusahaan yang berhubungan langsung dengan penggunaan dan pecemaran lingkungan (Asmiran, 2013).

\section{Definisi Operasional dan Pengukuran Variabel Kuantitas Pengungkapan Corporate Social Responsibility}

Kuantitas pengungkapan CSR dalam penelitian ini diukur dengan menggunakan metode skoring. Skor yang digunakan untuk mengukur kuantitas pengungkapan CSR adalah menggunakan skor 0 dan 1. Skor "0" digunakan apabila informasi yang terkait dengan item tersebut tidak ditemukan dalam publikasi perusahaa dan sebaliknya dengan skor "1". Apabila seluruh item telah diungkapkan maka nilai maksimal yang dapat dicapai perusahaan melalui penelitian ini adalah 149 item.

\section{Kualitas Pengungkapan Corporate Social Responsibility}

Kualitas pengungkapan CSR dalam penelitian ini juga diukur dengan menggunakan metode skoring, seperti yang telah dikembangkan oleh Raar (2002) pada penelitian sebelumnya. Raar (2002) mengukur pengungkapan CSR secara kualitas dengan skor 1 sampai dengan skor 7 . Definisi kualitas pengungkapan CSR dapat dilihat pada Tabel 1.

Tabel 1. Definisi Kualitas Pengungkapan CSR

\begin{tabular}{ll}
\hline \multicolumn{1}{c}{ Pengungkapan Kualitas } & \multicolumn{1}{c}{ Definisi Kualitas } \\
\hline $1=$ moneter & $\begin{array}{l}\text { Pengungkapan dalam satuan moneter/ mata uang. } \\
2=\text { non moneter }\end{array}$ \\
& $\begin{array}{l}\text { Kuantitatif dalam satuan angka seperti bobot, volume, } \\
\text { ukuran tetapi bukan mata uang. }\end{array}$ \\
$3=$ hanya kualitatif & Teks deskriptif saja. \\
$4=$ kualitatif dan moneter & Teks deskriptif dan mata uang. \\
$5=$ kualitatif dan non moneter & Teks deskriptif dan satuan angka. \\
$6=$ moneter dan non moneter & Kombinasi satuan mata uang dan angka. \\
$7=$ kualitatif, moneter, dan non & Teks deskriptif, satuan mata uang, dan satuan angka. \\
$\quad$ Moneter & \\
\hline Sumber: Raar, 2002 &
\end{tabular}

Penelitian ini menggunakan statistik deskriptif sebagai pengujian data. Statistik deskriptif (descriptive statistic) adalah fenomena atau kriteria dari data yang digambarkan oleh statistik. Statistik deskriptif menyediakan nilai frekuensi, pengukur tendensi pusat (measures of central tendency), dispersi, dan pengukur-pengukur bentuk (Jogiyanto, 2010).

\section{HASIL DAN PEMBAHASAN Statistik Deskriptif}

Berdasarkan hasil analisis deskriptif kuantitas pengungkapan CSR menunjukkan bahwa 32 perusahaan telah banyak mengungkapkan seluruh kriteria dari aspek strategi dan analisis, profil organisasi. Namun pada aspek material dan boundary, hubungan dengan pemangku kepentingan, 
aspek ekonomi, social dan lingkungan banyak perusahaan tidak banyak melakukan pengungkapan dalam aspek tersebut.

\section{Kuantitas dan Kualitas Pengungkapan CSR}

Untuk kuantitas pengungkapan CSR di tahun 2014 pengungkapan CSR tertinggi dilakukan oleh kode perusahaan INCO (PT. Vale Indonesia Tbk.), yaitu 87\% kemudian ITMG (PT Indo Tambangraya Megah Tbk.), yaitu 86\% dan ANTM (PT. Aneka Tambang Persero Tbk.), yaitu 84\%. Perusahaan lainnya memiliki tingkat persentase kuantitas pengungkapan CSR pada kisaran $50 \%$. Terdapat 4 aspek yang tingkat persentase pengungkapannya di atas $50 \%$, yaitu aspek strategi dan analisis (100\%), aspek profil organisasi (89\%), aspek tata kelola (61\%), serta aspek etika dan integritas $(78 \%)$.

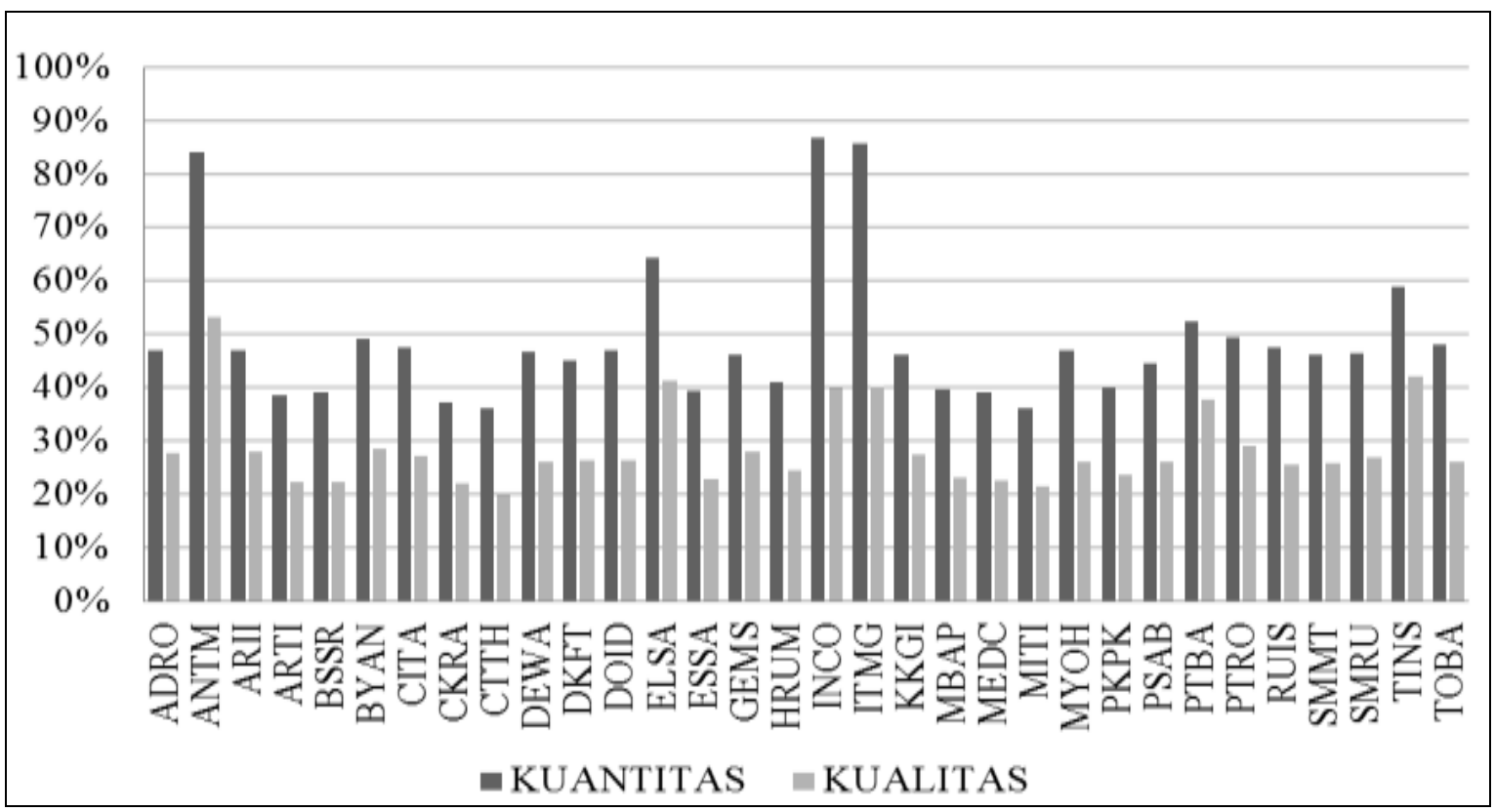

Gambar 1. Kuantitas dan kualitas Pengungkapan CSR Tahun 2014

Untuk kualitas pengungkapan CSR pada tahun 2014 tertinggi diraih oleh ANTM (PT Aneka Tambang Persero Tbk.) sebesar 53\%. Sedangkan perusahaan-perusahaan pertambangan lainnya memiliki kualitas pengungkapan di bawah $50 \%$. Hasil dari pengolahan data menunjukkan bahwa terdapat 2 aspek yang mengungkapkan kualitas pengungkapan CSR di atas 50\%. Kedua aspek tersebut adalah aspek strategi dan analisis (75\%) dan aspek profil organisasi (50\%). Itu artinya bahwa 32 perusahaan pertambangan yang dijadikan sampel kemungkinan telah mengungkapkan CSR-nya dengan kualitas yang tinggi pada kedua aspek tersebut. 


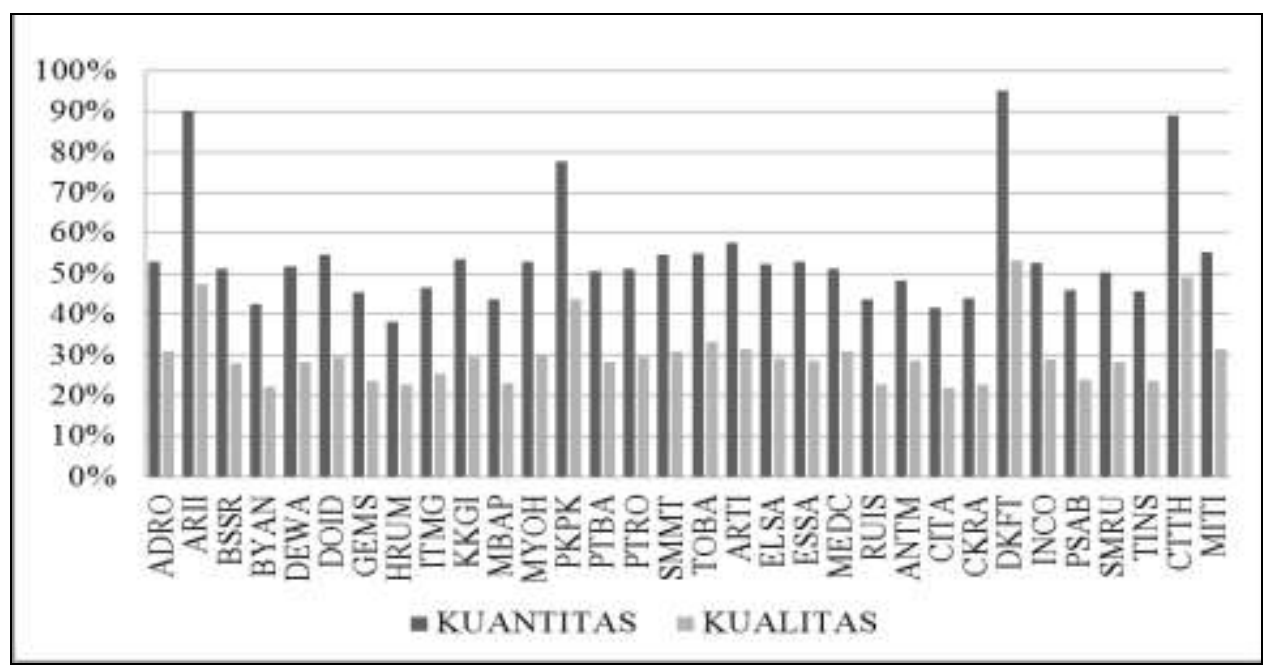

Gambar 2. Kuantitas dan kualitas pengungkapan CSR Tahun 2015

Gambar 2 mengungkapkan tingkat persentase kuantitas pengungkapan CSR masing-masing perusahaan pada tahun 2015. Secara kuantitas, pengungkapan CSR yang paling dominan dilakukan oleh PTBA (PT Tambang Batubara Bukit Asam Persero Tbk.) dengan tingkat persentase sebesar 95\%, ANTM (PT Aneka Tambang Persero Tbk.), yaitu 90\%, TINS (PT Timah Persero tbk.), yaitu 89\%, dan ELSA (PT Elnusa Tbk.), yaitu 78\%. Ini berarti bahwa keempat perusahaan tersebut kemungkinan telah memenuhi indeks GRI G4 dengan baik. Sedangkan, perusahaan-perusahaan lainnya rata-rata memiliki tingkat persetase pengungkapan tidak lebih ataupun tidak kurang dari 50\%. Aspek-aspek tersebut adalah aspek strategi dan analisis (100\%), profil organisasi (83\%), hubungan dengan pemangku kepentingan (63\%), aspek tata kelola (55\%), serta etika dan integritas (98\%).

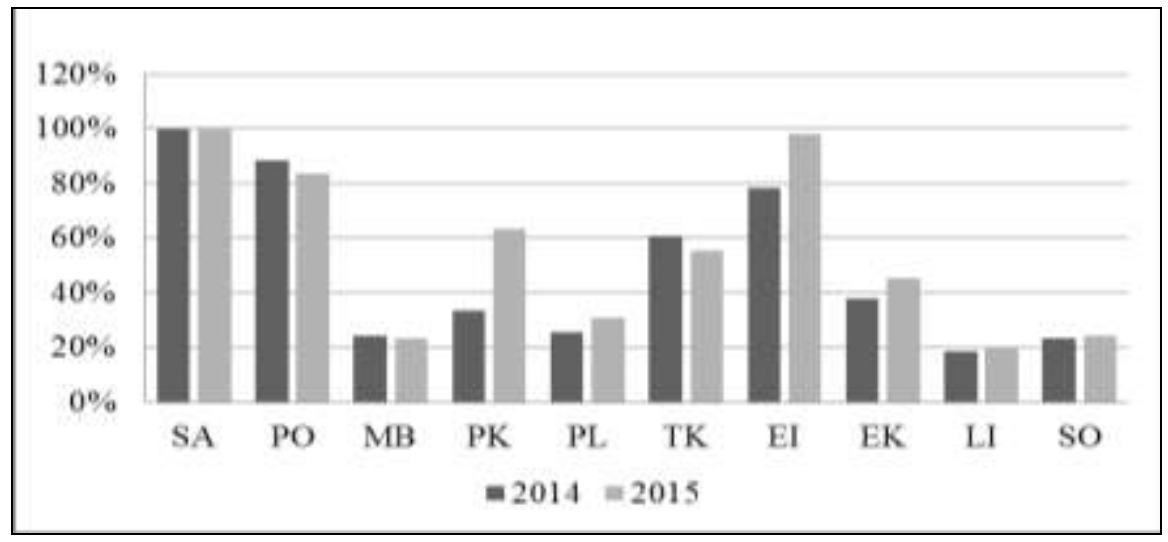

Gambar 3. Perkembangan Kuantitas pengungkapan CSR per aspek

Perkembangan kuantitas pengungkapan CSR dari tahun 2014 hingga tahun 2015, menunjukkan bahwa terdapat 1 aspek yang tidak mengalami perubahan yaitu aspek strategi dan analisis, yaitu $100 \%$. Artinya, 32 perusahaan sampel terus mengungkapkan dengan sangat baik kriteria-kriteria yang ada pada aspek ini. Aspek tersebut berisi mengenai visi, misi, strategi organisasi. Hal tersebut merupakan hal yang mudah bagi perusahaan untuk mengungkapkan. Selain 
itu pengungkapan yang tinggi baik secara kuantitas maupun kualitas dari tahun 2014 ke tahun 2015 adalah aspek profil dan organisasi serta Etika dan Integritas. aspek profil organisasi adalah aspek yang disajikan untuk memberikan gambaran keseluruhan tentang karakteristik organisasi. Sedangkan aspek etika dan integritas adalah aspek yang menggambarkan mengenai nilai, prinsip, standar, dan norma organisasi, mekanisme internal maupun eksternal untuk memperoleh masukan mengenai perilaku etis dan taat hukum, serta mekanisme internal dan eksternal untuk melaporkan permasalahan tentang perilaku yang tidak etis atau melanggar hukum dan masalah integritas.

Sedangkan 6 aspek yang mengalami kenaikan dan penurunan dengan pengungkapan terendah adalah aspek ekonomi, lingkungan, dan sosial. Aspek ekonomi di dalam pedoman pelaporan GRI G4 adalah aspek yang menggambarkan mengenai arus modal di antara pemangku kepentingan yang berbeda, dan dampak ekonomi utama dari organisasi di seluruh lapisan masyarakat. Aspek lingkungan di dalam pedoman pelaporan GRI G4 adalah aspek yang menggambarkan tentang dampak yang terkait dengan input (seperti energi dan air) dan output (seperti emisi, enfluen, dan limbah). Selain itu aspek ini juga menggambarkan tentang keanekaragaman hayati, transportasi, dan dampak yang berkaitan dengan produk dan jasa, serta kepatuhan dan biaya lingkungan. Aspek lingkungan cenderung rendah dikarenakan bagi industry pertambangan hal ini merupakan hal yang tidak mudah karena bagaimana mengambalikan alam setelah dilakukan eksplorasi terhadap lingkungan. Kuantitas pengungkapan CSR pada aspek social pada tahun 2014 hingga tahun 2015 masih tergolong rendah. Hal ini juga sejalan dengan penelitian yang dilakukan oleh Anggarani (2016) menemukan bahwa kategori pengungkapan lingkup sosial pada perusahaan pertambangan memiliki kuantitas pengungkapan sebesar 37\% untuk tahun 2014, dan 34\% untuk tahun 2015. Selain itu, Safitri (2013), B. Thunggono (2010) juga menunjukkan bahwa pengungkapan CSR untuk aspek ini masih tergolong rendah.

\section{PENUTUP}

Sesuai dengan pembahasan hasil analisis yang telah dilakukan pada bab sebelumnya, secara keseluruhan, rata-rata kuantitas pengungkapan CSR perusahaan sektor pertambangan dari tahun 2014 hingga 2015 adalah 52\%, rata-rata kulaitas pengungkapannya sebesar 29\%. Selain itu, Dalam lingkup profil dan strategi organisasi, rata-rata kuantitas pengungkapan CSR perusahaan sektor pertambangan tahun 2014 hingga tahun 2015 adalah 62\%, sedangkan kualitas pengungkapannya adalah 35\%. Dalam lingkup ekonomi, rata-rata kuantitas pengungkapan CSR perusahaan sektor pertambangan tahun 2014 hingga tahun 2015 adalah 42\%, sedangkan kualitas pengungkapannya adalah $29 \%$. Dalam lingkup lingkungan, rata-rata kuantitas pengungkapan CSR perusahaan sektor pertambangan tahun 2014 hingga tahun 2015 adalah 19\%, sedangkan kualitas pengungkapannya adalah 10\%. Dalam lingkup sosial, rata-rata kuantitas pengungkapan CSR perusahaan sektor pertambangan tahun 2014 hingga tahun 2015 adalah 24\%, sedangkan kualitas pengungkapannya adalah $12 \%$.

Penelitian ini memiliki keterbatasan yang perlu diperhatikan dalam menginterpretasikan hasil penelitian, yaitu tidak semua perusahaan di tahun 2015 telah menerbitkan laporan tahunan dalam penelitian ini. Hal ini mengakibatkan berkurangnya jumlah sampel perusahaan pertambangan yang akan diteliti.

Saran yang dapat diberikan untuk penelitian berikutnya adalah sebagai memperbanyak jumlah sampel perusahaan sehingga lebih luas interpretasi dari kepatuhan terhadap standar GRI.G4 . Selain itu sub sektor pertambangan melakukan fokus pengungkapan aktivitas CSR dalam aspek 
lingkungan, karena perusahaan sub sektor pertambangan memiliki dampak yang lebih besar pada aspek lingkungan.

\section{REFERENSI}

Anggarani, Alisa. (2016). Analisis tingkat kepatuhan pengungkapan CSR pada industri semen, sektor pertambangan, dan sektor perbankan periode 2013-2014. Jurnal. Surabaya: Fakultas Ekonomi dan Bisnis, Universitas Brawijaya.

Asmiran, Maya, T. W. (2013). Analisis faktor-faktor yang mempengaruhi pengungkapan Corporate Social Responsibility (CSR). Skripsi. Bandung: Fakultas Ekonomi, Universitas Pasundan.

B. Thunggono. (2010). Analisis pengungkapan informasi dalam sustainability reporting pada PT Kaltim prima coal Tahun 2008-2009. Artikel Jurnal. Salatiga: Universtias Kristen Satya Wacana.

Bonilla-Priego, Jesus; Font, Xavier; Pacheco-Olivares, Rosario. (2014). Corporate sustainability reporting index and baseline data for the cruise industry. Tourism management, vol. 44, pp. 149-160.

Elkington, J. (1997). Cannibals with forks The Tripple Bottom Line of 21 Century Business. Oxford: Capstone Publishing Ltd.

G4 Pedoman Pelaporan Berkelanjutan tentang Paduan Penerapan.

G4 Pedoman Pelaporan Berkelanjutan tentang Prinsip-Prinsip Pelaporan dan Pengungkapan Standar.

Hendriksen, E. (1991). Accounting theory, Fifth Edition. Https://www.mysciencework.com/publication/read/7242076/pengaruh-pengungkapancorporate-social-responsibility-csr-terhadap-abnormal-return\#page-null. Diakses pada Tanggal 18 November 2015.

Jogiyanto, Hartono. (2010). Metodologi penelitian bisnis: Salah kaprah dan pengalamanpengalaman, Edisi I. Yogyakarta: BPFE.

Kastutisari, Savitri \& Dewi Nurul, H. U. (2012). Pengaruh pengungkapan Corporate Social Responsibility (CSR) Terhadap Abnormal Return. Jurnal: STIE Perbanas Surabaya.

McWilliams, Abagail \& Siegel, Donald. (2001). Corporate social responsibility: A theory of the firm perspective. Academy of management review, vol. 26, pp. 117-127.

Noviana. (2010). Triple bottom line: Lebih dari sekadar profit. Http://swa.co.id/my-article/triple-bottomline-lebih-dari-sekadar-profit. Diakses pada tanggal 5 Oktober 2015.

Raar, Jean. (2002). Environmental initiatives: Towards triple-bottom line reporting. Corporate communications: An international journal, vol. 7, no. 3, pp. 169-183.

Safitri, Nanda. (2013). Analisa pelaporan pengungkapan Corporate Social Responsibility (CSR) berdasarkan pedoman Global Reporting Initiatives (GRI). Artikel Jurnal. Surabaya: Universitas Negeri Surabaya.

Sayekti, Yosefa \& Ludovicus. (2007). Pengaruh CSR disclosure terhadap earning response coefficient (Studi Empiris Pada Perusahaan yang Terdaftar di Bursa Efek Jakarta). Simposium Nasional Akuntansi X Makasar.

Undang- Undang No. 40 Tahun 2007 tentang Perseroan Terbatas. 